\title{
BIOAUGUMENTATION EFFICIENCY OF MICROBIAL BACTERIA AND STRATEGY FOR ITS RECOVERY THROUGH ADDITION OF NPK FERTILIZERS AND THE STUDY OF ITS MORPHOLOGY
}

\author{
Umema Mohsin ${ }^{1 *}$, Madan Lowry $^{2}, \operatorname{Ranu}_{\text {Sharma }}{ }^{1}$ and Mamta Moond ${ }^{2}$ \\ ${ }^{1}$ Department of zoology, Mahatama Joyti Rao Phule University, Jaipur, India \\ ${ }^{2}$ Department of zoology, University of Rajasthan (Centre for Advanced Studies), Jaipur, India \\ *Corresponding author's email: umemamohsin@yahoo.in
}

\begin{abstract}
The study basically focuses on hydrocarbon contamination that is caused because of bacteria present in the soil. Transport Nagar Area in Jaipur is mostly covered with garages and hence surrounded by crude oil, petrol, diesel and other fractions of crude oil. Soil and ground water are polluted with diesel fuel from leaking underground storage tanks which happens as a result of accidental spills and leakage from pipelines which causes harm to the both flora and fauna. In the study conducted the treatment samples were observed with significant difference with the control. The microbial count was maintained in the range of $3.86 * 10^{4}$ - THBP per gram soil and $1.87 * 10^{3}$ - PDBP per gram soil. The highest bacterial growth was showed after 60 days with $40 \%$ NPK because of the presence of an inorganic nutrition, bacterial activity and as a result petroleum degradation was maximum.
\end{abstract}

Keywords: fertilizer; hydrocarbon; heterotrophic bacteria; nutrient

\section{Introduction}

Jaipur is the capital and large city of the Indian state of Rajasthan in Northern India covering a geographical area of 11061.44 sq. Km. The study basically focuses on hydrocarbon contamination that is caused because of bacteria present in the soil. For this an extensive study on the soil was carried out in Transport Nagar Area, Jaipur. This place is mostly covered with garages hence soil of this area is polluted by petrol, diesel and other fractions of crude oil. Most of the times, Soil and ground water are polluted with diesel fuel from leaking underground storage tanks. This mostly happens as a result of accidental spills and leakage from pipelines. These compounds get transported to soil, water intakes or ground water reservoirs and cause a lot of harm (Gallego et al., 2001). The carbon number of diesel oil hydrocarbons is between 11 and 25 (2000 to 4000 hydrocarbons) and the distillation range is between 180 to $380{ }^{\circ} \mathrm{C}$ (Durand et al., 1995). Diesel oil is a complex mixture of normal, branched and cyclic alkanes and aromatic compounds. It's properties are viz. low water solubility, high adsorption coefficient and high stability of the aromatic ring (Dean et al., 2002; Kanaly and Harayama, 2002; Kropp and Fedorak, 1998; Van et al., 2003). As a result, it has been concluded that diesel and petrol fuel are priority pollutants and are capable of causing bio-hazardous effects on both human and other living organisms in the environment (Kramer and Van 1990; Refaat et al., 2008; Richardson, 1996). Hydrocarbon contamination is a very serious problem whether it comes from petroleum or other toxic organic matter. These hydrocarbons also contain heavy metals and much of the heavy metal content of diesel or petroleum is associated with complex structures called porphyrins.

The biodegradation of these compounds mostly occurs naturally in the environment. It has been known for over 50 years that degradation of petrol or diesel occurs because of bacteria feeding on it. These bacteria have been isolated from soils, surface areas, oil spills etc. (Huy et al., 1999).

The ability to isolate high numbers of certain oil-degrading microorganisms from petroleum-contaminated environment is commonly taken as evidence that these microorganisms are the active degraders of that environment (Okerentugba and Ezeronye, 2003).

\section{Materials and Methodology}

The soil samples were collected from 3 locations of Transport Nagar, Jaipur. Transport Nagar is a densely populated with a lot of garages and industries which is the reason why the soil in this area is contaminate by petrol. 
Soil pollution in this area is increasing at an alarming rate because of this very reason.

Soil samples were collected on July, 2014 from three different motor garages in this region. Sample was collected from a depth of about $5 \mathrm{cms}$ from one square metre region and was brought to the laboratory in sterile bags. Normal soil samples were collected from the same area.

\section{Estimation}

\section{Total Hetrophilic Bacterial Population counts}

THBP (Benson, 1998) and Serial dilution method is used. Accurate of soil dilution is used on suitable nutrient agar medium. The pour plate or spread plate method can be employed for this method. After incubation, colonies are counted with the help of quebac colony counter.

For NA $10^{-5}-10^{-6}$ dilution series was maintained.

Calculation for total colony counts was as follows:

Colonies per gram of soil at a particular dilution $=\frac{\text { Average number of colonies X Dilution factor }}{\text { Volume of dilution added to the plates }}$

Total colonies per gram of soil sample

$$
=\frac{\text { Total no. of colonies at every dilution }}{\text { Total no. of dilution used }}
$$

\section{Petroleum Degrading Bacterial Population (PDBP)}

The serial dilution of the Soil samples (upto $10^{6}$ ) were prepared. $1 \mathrm{ml}$ spoil suspension in each $10^{3}, 10^{4}, 10^{5} 10^{6}$ dilutions was poured with MSM media. MSM media prepared from the following composition $(\mathrm{gm} / \mathrm{L}): 2.2 \mathrm{gm}$ $\mathrm{K}_{2} \mathrm{PO}_{4}, 0.732 \mathrm{~g} \mathrm{KH} \mathrm{PO}_{4} 1.0 \mathrm{gm}\left(\mathrm{NH}_{4}\right)_{2} \mathrm{SO}_{4}, 0.2 \mathrm{gm} \mathrm{Mg}$ $\mathrm{SO}_{4} .7 \mathrm{H}_{2} \mathrm{O}, 18 \mathrm{gm}$ Agar. The commercial 2T oil was added as the sole carbon source to the autoclaved media morphologically. The plates were incubated for 7 days at $37^{\circ} \mathrm{C}$ temperature. After incubation the bacteria colonies were counted. At last NPK fertilizers are added to the soil sample to check the colonies of microbes. NPK in the ratio of (19:19:19) in different concentrations $(10,20,40 \mathrm{gm} / 100$ gm soil) mixed in water equal to $33 \%$ of the total WHC of soil sample. (Madan Lowry, Mamta Mood, 2015)

\section{Isolation of bacterial cultures and Morphological Characterization}

In laboratory analyses, enrichment and isolation of oil degrading bacterial cultures were done using minimum agar media with $2 \mathrm{~T}$ oil as substrate and a serial dilution agar plating technique on nutrient agar media respectively. The isolated bacterial cultures were characterised by morphologically.

\section{Result and Discussion}

Morphology and cultural characteristics of bacterial isolates are shown in Table 1. The effect of time in petroleum degradation was significant. The petroleum degradation rate decreased with increasing time (Table 3). The highest bacterial growth was showed after 60 days with $40 \%$ NPK because of the presence of an inorganic nutrition, bacterial activity and as a result petroleum degradation was maximum (Fig 1).

Table 1: Morphology and cultural characteristics of bacterial isolates

\begin{tabular}{|c|c|c|c|}
\hline $\begin{array}{l}\text { S. } \\
\text { N. }\end{array}$ & $\begin{array}{l}\text { Isolate } \\
\text { Number }\end{array}$ & Colony Morphology & Microscopy \\
\hline 1 & $\mathrm{~T}_{1}$ & $\begin{array}{l}\text { Whitish colony, circular } \\
\text { form, Elevation pulvinate } \\
\text { with reverse side, beige } \\
\text { colourless }\end{array}$ & $\begin{array}{l}\text { Well- } \\
\text { developed } \\
\text { margins are } \\
\text { entire }\end{array}$ \\
\hline 2 & $\mathrm{~T}_{2}$ & $\begin{array}{l}\text { Light yellowish in colour, } \\
\text { irregular form, elevation } \\
\text { umbonate }\end{array}$ & $\begin{array}{l}\text { Margins are } \\
\text { irregular } \\
\text { and } \\
\text { undulate }\end{array}$ \\
\hline 3 & $\mathrm{~T}_{3}$ & $\begin{array}{l}\text { White in colour, irregular } \\
\text { form, elevation-umbonate }\end{array}$ & $\begin{array}{l}\text { Well } \\
\text { developed } \\
\text { and margins } \\
\text { are undulate }\end{array}$ \\
\hline 4 & $\mathrm{~T}_{4}$ & $\begin{array}{l}\text { White in colour, irregular } \\
\text { (spreaded) form; elevation } \\
\text { umbonate, reverse side being } \\
\text { white in colour }\end{array}$ & $\begin{array}{l}\text { Lobate } \\
\text { margins in } \\
\text { zig-zag } \\
\text { chain like } \\
\text { fashion }\end{array}$ \\
\hline
\end{tabular}

\section{Total heterotrophic bacterial count at $10^{5}$ concentration}

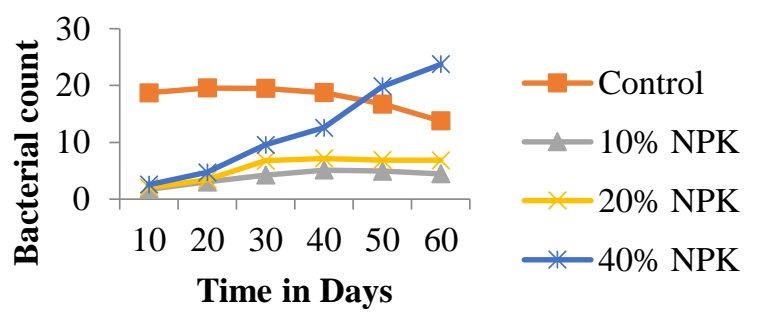

Fig 1: Total heterotrophic bacterial count (THBC) at $10^{5}$ concentration

Table 3: Petroleum degrading bacterial population (PDBP) at $10^{4}$ concentration

\begin{tabular}{|l|l|l|l|l|l|l|}
\hline Days & 10 & 20 & 30 & 40 & 50 & 60 \\
\hline $\begin{array}{l}\text { Contro } \\
1\end{array}$ & $\begin{array}{l}5.7 \\
6\end{array}$ & 5.45 & 5.05 & 4.9 & 4.2 & 3.95 \\
\hline $\begin{array}{l}10 \% \\
\text { NPK }\end{array}$ & 6.2 & 9.75 & 12.0 & $\begin{array}{l}17.5 \\
8\end{array}$ & 25.76 & 39.5 \\
\hline $20 \%$ & 6.9 & 11.7 & 22.4 & 32.3 & 39.56 & 42.8 \\
NPK & 5 & 2 & 3 & & & 7 \\
\hline $40 \%$ & 7.8 & 13.5 & 27.5 & 58.5 & 103.5 & $\begin{array}{l}106 . \\
\text { NPK }\end{array} 6$ \\
\hline
\end{tabular}


Madan et al. (2015) in the study showed that the hydocarbon degrading bacterial count increased with the applied fertilizers. Sang-Hwan et al. (2007) made a similar observation and concluded that hydrocarbon degrading bacterial populations increased rapidly during 30 to 105 days of testing period. Ramsay et al. (2000) in the study of bioremediation on microbial population observed that fertilizer increment had effect on the growth of hydrocarbon degrading bacteria in soil.

In the study conducted the treatment samples were observed with significant difference with the control. The microbial count was maintained in the range of $3.86 * 10^{4}$ - THBP per gram soil and $1.87 * 10^{3}$ - PDBP per gram soil.

Before and after addition of NPK fertilizers the CFU of microorganisms was maintained in the range of $10^{4}$ to $10^{5}$ CFU per gram of soil. The result shows the pattern of growth differs from organism to organisms. The factors that determine this pattern of growth include the incubation period, the nature and composition of the nutrient in which the organism is growing. The soil description showed that the soil did not fulfill the NPK requirements for an efficient capable and biodegradation process. Therefore, these elements were added as supplements in the form of NPK inorganic fertilizer to provide proper nutrients required for the bioremediation process.

\section{References}

Benson HJ (1998) Microbiological applications: A laboratory manual in general microbiology. McGraw-Hill College.

Dean-Ross D, Moody J and Cerniglia CE (2002) Utilization of mixtures of polycyclic aromatic hydrocarbons by bacteria isolated from contaminated sediment. FEMS Microbiol. Ecol. 41(1): 1-7. DOI: $10.1111 / \mathrm{j} .1574-$ 6941.2002.tb00960.x

Durand JP, Beboulene JJ and Ducrozet A (1995) Detailed characterization of petroleum products with capillary analyzers. Analusis 23(10): 481-483.

Gallego José LR, Lordedo J, Llamas JF, Vazquez F and Sanchez J (2001) Bioremediation of diesel-contaminated soils: Evaluation of potential in situ techniques by study of bacterial degradation. Biodegradation 12(5): 325-335. DOI: 10.1023/A:1014397732435
Huy NG, Amada K, Haruki M, Hun NB, Hang DT, Ha DTC, Imanaka T, Morikawa M and Kanaya S (1999) Characterization of petroleum-degrading bacteria from oil contaminated sites in Vietnam. J. Biosci. Bioeng. 88(1): 100- 102. DOI: $10.1016 / \mathrm{S} 1389-1723(99) 80184-4$

Kanaly RA and Harayama S (2002) Biodegradation of high molecular weight polycyclic aromatic hydrocarbons by bacteria. J. Bacteriol. 182(8): 2059-2067. DOI: 10.1128/JB.182.8.2059-2067.2000

Kramer PGN and Van der Heijden CA (1990) Polycyclic aromatic hydrocarbons (PAH): Carcinogenicity data and risk extrapolations. Toxicol. Environ. Chem. 16(4): 341-451. DOI: $10.1080 / 02772248809357271$

Kropp KG and Fedorak PM (1998). A review of the occurrence toxicity and biodegradation of condensed thiophenes found in petroleum. Can. J. Microbiol. 44(7): 605-622. DOI: $10.1139 / \mathrm{w} 98-045$

Lowry M and Moond M (2015) A Strategy to Improve Efficiency of Hydrocarbon Degrading Microbial Flora through Biostimulation Approach. Int. J. Curr. Microbiol. App. Sci. 4(6): 111-117.

Okerentugba PO and Ezeronye OU (2003) Petroleum degrading potentials of single and mixed microbial cultures isolated from rivers and refinery effluents in Nigeria. Afr. $J$. Biotech. 2(9): 288-292. DOI: 10.5897/AJB2003.000-1058

Ramsay AM, Swannell.Warren PJ, Duke A, Sh T and Hill R (2000). "Effect of bioremediation on the microbial community in oiled mangrove sediments. Marine Pollution Bulletin 41(7): 413-419. DOI: 10.1016/S0025326X(00)00137-5

Refaat AA, Attia NK, Sibak HA, El Sheltawy ST and El Diwani GI (2008) Production optimization and quality assessment of biodiesel from waste vegetable oil. Int. J. Environ. Sci. Tech. 5(1): 75-82. DOI: 10.1007/BF03325999

Richardson M (1996) Environmental Xenobiotics. CRC Press 1118.

Sang-Hwan 1, Seokho 1, Dae Yaeon K and jeong-gyu K (2007) Degradation characteristics of waste lubricants under different nutrient condition. J. hazard. mater. 143: 65-72. DOI: $10.1016 / j$.jhazmat.2006.08.059

Van Hamme JD, Singh A and Ward OP (2003) Recent advances in petroleum microbiology. Microbiol. Molecul. Bio. Rev. 67(4): 1092-2172. DOI: 10.1128/MMBR.67.4.503549.2003 